\title{
Substantiation of averaging the content of mined ores with account of their readiness for mining
}

\author{
Tursyn Kalybekov ${ }^{1}$, Kanay Rysbekov ${ }^{1 *}$, Dilda Nauryzbayeva ${ }^{1}$, Ayan Toktarov $^{1}$, and \\ Yryszhan Zhakypbek ${ }^{1}$ \\ ${ }^{1}$ Satbayev University, 22a Satpayev St., Almaty, Republic of Kazakhstan
}

\begin{abstract}
Paper demonstrates the importance of substantiating the reserves volumes ready for mining in extraction units, in accordance with the mine output capacity, averaging mode and reducing the variation in the mined product quality. Rational methods of planning mining operations based on innovative technological solutions to achieve highquality ore mass uniformity in terms of mineralogical composition are presented. Optimization of mineral extraction scheduling is possible with a comprehensive analysis of the existing situation and determining a wellfounded method for mining operations. Averaging the mined ores content by two components requires a change in their volume planned for separate panels. Based on critical analysis and personal analytical research, a new method has been developed for averaging the mineral raw materials content. The method of ore content bottom-hole averaging in underground mining is substantiated, taking into account the output distribution over extraction units and obtaining a uniform quality of the extracted raw materials. The proposed method of averaging the minerals quality differs from the existing ones by the optimal ore volumes distribution in accordance with their content directly in the mined-out faces of the panels during the period of the field exploitation by underground method.
\end{abstract}

\section{Introduction}

When scheduling mining operations, technical solutions should be substantiated to ensure the optimal concentration of mining blocks and panels, to exclude the lack of their concentration and great number of horizons when mining the mineral deposits. Under these conditions, an important task of subsoil exploitation is to confirm the readiness of reserves for mining, taking into account averaging the mined ores content. In practice, in order to average the mineral raw materials quality, the measures are performed, as a result of which the variation of standard indicators for a specified ore volume is stabilized within certain limits. In mining operations, there are techniques for mixing in various ways of the mined volumes of ore, differing in mineralogical and physical properties during the mining period or in special warehouses. In the process of industrial mining of any field, the standards should be

\footnotetext{
* Corresponding author: kanay r@mail.ru
} 
substantiated of the readiness of reserves for mining in order to provide consumers with the required quality of the extracted raw materials. Under these conditions, substantiation of the optimal output from each extraction unit helps to ensure a rational level of completeness of mineral raw materials extraction, the most complete, comprehensive and efficient use of the balance reserves of the main and adjacent to them ore deposits [1].

The qualitative composition of the mined mineral depends on the mining-andgeological conditions, technological and mining-engineering factors of the mined field. In this regard, during the period of mining operations, it is necessary to study the quality variation of the extracted mineral raw materials over horizons, blocks and panels, the presence of waste rocks and substandard ores within the exploited deposit boundaries. The level of averaging of ore qualitative composition is influenced by the number of stope faces in operation, as well as the ore content in them. When managing ore mining process in the mode of averaging and reducing the quality, the reserves volumes ready for mining in extraction units should be substantiated. Under these conditions, the standards of reserves, which have already been prepared and are ready for mining should have a reserve to compensate for the irregularity of mining operations [2 -5].

The ore quality stabilization methods, when mining ore by underground method, are influenced by organizational and production-technological measures. The organizational component includes the planning, organization and management of mining recovery, conducted in the mode of averaging the ore quality in the mine technological scheme [6]. The main organizational measures objective is to provide a specified level of the ore output quality indicator. Organizational impacts on the quality characteristics of the mined ore influence on the quantitative and qualitative dependences, based on which the quantity and quality of ore are set for ensuring an average level of output quality indicators or the ore flow for a certain period of time. At the stage of operating management, the unit volumes of ore mass not uniform in quality, which is involved in the stabilization process along with averaging are significantly reduced, which leads to a decrease in the range of ores variation. Production-technological measures are conducted with the purpose of mixing the unit volumes of ore mass to achieve uniform managed component distribution in the resulting volume of raw materials.

When decreasing the content in underground mining operation, the costs required for metal extraction increase, therefore, ores with a high ore content are primarily exploited [7]. In this regard, the mining technology improvement cannot reduce the minimum energy required for the raw materials extraction when the deposits are dispersed at different horizons. The results indicate that the ore content in separate mines is gradually decreasing, while energy production and consumption are increasing. This tendency has been proven in the copper ores mining, as more accurate information was available relative to energy use and mineral quality [8]. In this regard, the ore content reduction is no longer a theoretical problem, but is a real problem under the conditions of existing mines.

When extracting the mineral raw materials by underground method, operating quality control of the mined minerals in accordance with the readiness of reserves for mining is performed by regulating the faces number. In addition, the sufficient conditions are being created for scheduling and managing mining operations.

\section{Literature review}

In underground mining, order of mining has great significance, as it allows to mine out the field's reserves in any direction, including from bottom to top [9]. Under these conditions, unification of ore flows in a quarry and in mine sufficiently widens the technological capabilities for smoothing the natural ore quality variation at the first stage due to the general scheduling and current planning of mining operations. The ore quality stabilization methods 
are divided into organizational and technological. Organizational methods are carried out by means of organizational-managerial activities in the scheduling and current planning of mining operations, as well as when managing the specific ore flows, from faces to consumers. Technological methods of ore quality stabilization include the methods based on the creation and use of special structural systems for averaging the bunker type or stack type, which introduce certain adjustments to the mine technological scheme.

The problem of forming the ore raw materials quality relates to the solution of a number of problems for deposits mapping, designing mining and processing mining enterprises, taking into account the quality characteristics of the mined ores [10]. As a result, the issues have been successfully solved on stabilizing and averaging the ores in underground conditions and on the surface in case of bulk mining, separate mining, and processing according to technological types and grades.

The basis for the rational performance of a mining enterprise in modern economic conditions is an effective production planning system [11]. The decisive factors influencing preparing of the mine operation production program for a certain period of time are the state of the stope faces, as well as reserves prepared and ready for mining. Depending on mining-and-geological conditions, the sequence optimization of mine working development and the availability of reserve faces maintains the mine capacity and planning processes, as well as provision of the enterprise with reserves ready for mining with account of their averaging to stabilize the ores quality.

Development of the technology for managing and controlling the quality of mineral raw materials extraction and processing based on fields modelling and ore flow management is relevant for large mining-and-metallurgical enterprises [12]. The development of intelligent technology for monitoring and managing the ore flows quality when mining the multicomponent ores involves solving the following problems: creating digital geological models of fields that provide the basis for preparing the systems of long-term and operating planning; development of a system for automated planning of mining operations and technological solutions that guarantee the specified standards and mining rates, as well as quantitative and qualitative characteristics of the formed ore flows; creating a system of quality control for the ore transported through the use of technical means of the components content operating measurement that could operate in a continuous monitoring mode. In accordance with global trends in the technical retooling of underground mines, they, along with mining operations, are entrusted with the functions of primary ore preparation and bringing the mined ore quality to a state that exceeds the quality of ore in the mined-out deposits [13 - 15].

The managing system of the ore quality stabilization in the underground mine includes an averaging and mixing subsystem [16]. The information is being obtained by the group of analysis and development of operating decisions, from where the most rational options for actions are transferred to the mine technical management as recommendations for implementation [17]. The scientific and technical substantiation of the mine system for the formation of a stable mined ore mass composition includes information on the qualitative and quantitative characteristics of ore in the bowels and in the main nodes of the technological mine scheme. In addition, it includes planning and organization of mining operations in the mode of stabilizing the material composition of ore mass.

The standards stabilization is ensured by qualitative mined ore uniformity in the ranges that are permissible in a technical and economic term, by managing the technological processes and conducting appropriate organizational and technical measures at various stages of mining, transportation and raw materials extraction [18]. One of the regulating elements, in order to achieve the necessary qualitative ore mass uniformity, is the averaging its quality, achieved by mixing the ore volumes differing in mineralogical and chemical composition, and, in some cases, in physical properties. The ore quality stability is assessed by the deviation 
value of the components content from the average value at a controlled point of time.

The decrease in the range of raw material variations during averaging provides significant quality uniformity and content stability of the ore flow output entering the processing enterprise with a favourable low-frequency ore flow [19].

Under these conditions, with the purpose to study the content changes dynamics of the ore flow entering the processing enterprise, a stability criterion is proposed by quality and output capacity, taking into account the copper content deviations from the plan value for mining-engineering productive capacity, which makes possible to plan and analyse the mine operation.

In underground mining operations, methods for managing the ore quality during its mining can be: mining-technological, organizational and economic [20]. Miningtechnological methods can be implemented by selecting the development systems and their parameters, which ensure a corresponding change in the output quality, as well as improving production processes of stope works with additional measures included in the technological scheme. Organizational management of ore quality is performed through measures that create a specific order of ore extraction, delivery, transport, loading and unloading the storage capacities, as well as additional scheduling of mining operations. Economic management of ore quality is based on the study of the ore raw materials quality influence on the final results of the mining-and-metallurgical complex activity with an integrated economic assessment of decision options in accordance with the actual production capabilities of the mine and market conditions.

The central place in the planning process is occupied by an advanced block model that includes probabilistic data of the project composition [21]. It is detailed in the course of mining operations development with the aim to make partially weighted decisions for improving output and minerals content $[22,23]$. Simulation modules are developed with account of usefulness for various operators, each of them contains a summary table of the main results, as well as the graphs of key efficiency indicators. Significant results require that the input data are in correlations with the production environment between mineral components, production relation and time. In this regard, the data are used on mining in real operations and ore content variability, adjusted for potential proposals of development.

The growth of consumer requirements for product quality and ecological safety of production technology, an objective decrease in the mineral raw materials quality stimulate the search for new organizational and technical-and-economic solutions on increasing the competitiveness of mining companies [24]. The diversification strategies development based on the principles of integrated resources use requires consistent decisions-making. The effective mineral raw materials use includes application of the rational methods for planning mining operations and waste processing based on innovative technological solutions in the subsoils development.

When using the proposed structure, it is possible to systematically solve the problem of ore quality management in the process of its underground mining [25]. At the first stage of management, mining operations are being planned providing an average regulated metal content in annual, quarterly and monthly output. In this case, certain mining objects and extraction volumes are set with the determination of the main technical and technological means of mining operations and, accordingly, quality management methods used at this stage. Under these conditions of operating planning and management of mining operations with simultaneous forming the required absolute ore quality level, the current indicators deviations are minimized if compare with the average regulated value. To increase the metals concentration in the ore mass and to classify it by grades, the modern means of preliminary concentration and ore sorting are used. Then, at the last stage of output quality control, internal uniformity of the mined ore mass composition is ensured by means of averaging in the mine workings or on the mine surface. In addition, the output control is 
performed by all quality indicators of raw materials supplied to consumers.

Systems and technologies that facilitate to optimize the planning of mining operations can be extended to several mines [26-28]. This task is an integrated system for planning the production activity at a mining enterprise. When optimizing, the planners manage to know what is happening with the current production configuration. By changing the certain values and by restarting, optimizers will be able to notice the influence of changes within 5-10 minutes. The described results evidence two main advantages of this system: comprehensive analysis of the situation and obtaining quick optimization of mining operations plans, taking into account the extracted mineral raw materials quality.

Mining companies have not been able to accurately assess the ore content, despite good sampling of quality control and geological control $[29,30]$. Regulating the ore content with proper management will lead to a significant improvement in the processes in the whole chain of extraction cost development. Key recommendations relate to the observations and conclusions of research aimed at improving ore content control, an integrated approach to sampling, modelling of resources and overall quality management of the mined mineral $[31,32]$.

The formation of mined ores with a certain quality is a complex process, depending on a number of factors related to the natural ores properties and the technology of ore bodies extraction. This stage is the most important in the formation of merchantable ores intended for processing [33]. For this purpose, it is necessary to solve the problems of averaging the ore content at the stage of scheduling the deposit mining and to determine their rational level. It is important to choose ways for output quality stabilization precisely for the underground mine, taking into account the readiness of reserves and the requirements for their subsequent processing.

When conducting underground mining operations, a significant dependence has been set of the mined ore depth and content influence on the use of electricity [34]. Ore quality and the depth of mining have not significant influence on the use of energy for underground mining operations during ore leaching $[35,36]$. Energy costs are accelerated significantly when the ore content is below $0.5 \%$, and flotation is becoming increasingly difficult in the conditions of current efficiency [37]. The study has revealed that a decrease in the ore quality depends on the depth of mining operations and an increase in energy costs.

The development of various ore grades, mainly as a result of growing demand and rational technological improvements, as well as mining the low-grade ores, have become profitable. The increase in costs associated with a decrease in the mined ore content limits the availability of mined resources in terms of sustainability.

\section{Methods}

The paper proposes a method for bottom-hole averaging the mineral raw materials, taking into account the volume and content of ore mined in extraction units during underground mining operations [38]. The stabilization of the extracted mine products quality, with account of the averaging the ores, should be provided at the stage of scheduling the mineral resources mining. An unreasonable degree of minerals readiness for mining in underground mines requires the implementation of significant amounts of mining operations, so a sharp excess of the adopted reserve standards in the market terms is undesirable [39-42]. Therefore, the reserve standards accepted for the conditions of a particular mined field should correspond in the mining scheduling to the design capacity of the underground mine in terms of the degree of readiness and with account of the extracted raw materials quality.

When conducting mining operation, averaging of the extracted ore quality is influenced by several characteristic peculiarities of technological factors in the used systems of mining 
(Fig. 1). Under these conditions, the sequence of mining at any mine horizon includes the following main modes of mining: sequential and selective.

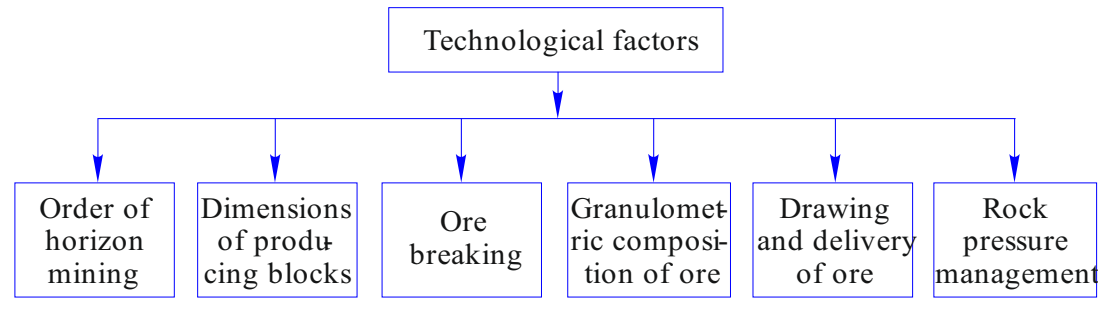

Fig. 1. Technological factors determining the ore flow quality and its stability.

Therefore, the substantiation of the rational methods influencing the quality of the ore flow and the stability of the mined ore content in the conditions of underground mining operations is important in mining the field.

The number of mining faces in operation influences on the determining the level of averaging the qualitative composition of the total ore flow mined. In the case of underground mining operations, the availability of reserves prepared and ready for mining facilitates the management of the mining process in the averaging mode and allows to reduce variation in the ore flow content. The number of extraction units in operation depends on the mine capacity and the order of mining the deposits. Thus, their number should correspond to the accepted sequence of the raw materials extraction, taking into account the planned mining of minerals.

In the conditions of intensive deposits exploitation and a regular decrease in the mined ores quality content, mainly due to mining the richer reserves, a search should be made for new engineering and mining-technological solutions for the bottom-hole averaging of minerals mining. For this purpose, in underground mines, it becomes possible to increase the practical use and create fundamentally new technical solutions that correspond to the mining-and-geological conditions of mining operations. When mining deposits, ensuring the required ore quality depends on the state of reserves ready for mining and the ore mass in them at any stage of mineral raw materials extraction.

The mined ores quality stabilization requires an analysis of their content in extraction units and the distribution of useful components in them. Under these conditions, the geological and surveying service of the mine should determine in advance the volumes and quality of ore mined from operating extraction units to ensure the planned indicators of raw material extraction in the mine. Then the reserves readiness norms, taking into account the content and volumes of ore planned for mining by panels at the enterprise, are substantiated in the following sequence. The task of the mine surveying service is to calculate the ratio of ore volumes, which are supplied, for example, from the current four extraction units. To determine its average content, a method is used of determining the weighted average mined ore value.

Using the method of determining the weighted average value, the average content of ore mined is found and the ratio of the mineral raw materials volumes, which is supplied from the current four extraction units, is calculated with two useful components using the formula:

$$
\left(C_{1}+C_{2}\right)_{t}=\frac{\left(C_{1}+C_{2}\right)_{1} V_{1}+\left(C_{1}+C_{2}\right)_{2} V_{2}+\left(C_{1}+C_{2}\right)_{3} V_{3}+\left(C_{1}+C_{2}\right)_{4} V_{3}}{V_{1}+V_{2}+V_{3}+V_{4}},
$$

where $\left(C_{1}+C_{2}\right)_{t}$ is content of useful components in merchantable ore; $\left(C_{1}+C_{2}\right)_{t}$ is content of useful components in extraction unit; $V_{1}, V_{2}, V_{3}, V_{4}$ are ore volumes mined from extraction units. 


\section{Results and discussion}

The data of mining operations scheduling allows determining the quality and volume of ore supplied to the processing enterprise, since at this stage the planned indicators are known of reserves extracted from each operating face in the mine. Therefore, when conducting underground mining operations, data on the quality of reserves ready for mining, in the mined panels or blocks, contribute to the successful decision for planning bottom-hole averaging of the ore. To do this, it is necessary to know the planned values and quality indicators of mined ores located in extraction units, as well as the planned output in the mine as a whole.

Pillar-and-panel mining system is used in the underground mines of "Kazakhmys Corporation" LLP for mining the shallow and inclined ore deposits with stable ores and host rocks with average ore value [43]. In case of underground mining of horizontal and slightly inclined ore deposits with an inclination angle of up to $10^{\circ}$, the panel drifts are driven beginning with supply gate, panel inclines every $40 \mathrm{~m}$, a stope drift, driven beginning with the first incline and a ventilation drift is located in the centre of the chamber (Fig. 2). Under these conditions, cutting operations include volumes of slanting the stope drift to a width equal to the span between the pillars, and to a length equal to the width of three chambers. Then, for conducting mining operations, a method is proposed for bottomhole averaging of copper-zinc ore with a pillar-and-panel mining system, the essence of which is as follows.

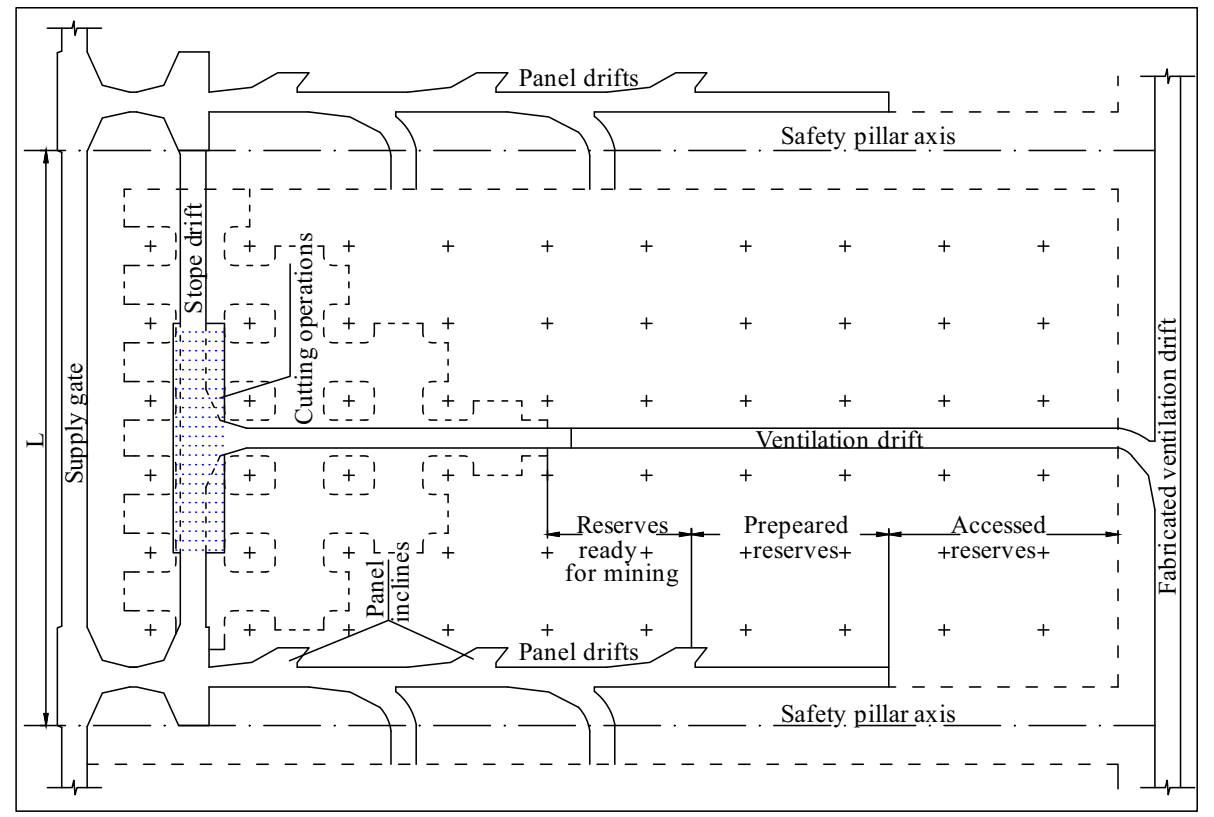

Fig. 2. Pillar-and-panel mining system.

In the extraction units operated simultaneously, copper and zinc content in the ore of the panels, as well as the planned daily ore output in the panels, are shown in Table 1. For these conditions, based on the indicated data, the mined ore averaged volume planned for mining is determined from each extraction unit with account of the existing content deviations. Then, for optimal planning of minerals mining, a planned weighted average value is determined of the copper and zinc content in the mined ore. 
Table 1. The content of copper and zinc in the ore of the panels.

\begin{tabular}{|c|cc|c|}
\hline Element & Rank & Content, \% & $\begin{array}{c}\text { Weighted average } \\
\text { content, \% }\end{array}$ \\
\hline \multirow{3}{*}{$\mathrm{Cu}$} & $\mathrm{C} 1.1$ & 0.97 & \multirow{2}{*}{1.185} \\
\cline { 2 - 3 } & $\mathrm{C} 1.2$ & 1.31 & \multirow{2}{*}{1.25} \\
\cline { 2 - 3 } & $\mathrm{C} 1.3$ & 1.07 & \\
\cline { 2 - 3 } & $\mathrm{C} 1.4$ & 1.39 & \multirow{2}{*}{2.020} \\
\hline \multirow{3}{*}{$\mathrm{Zn}$} & $\mathrm{C} 2.1$ & 1.91 & \\
\cline { 2 - 3 } & $\mathrm{C} 2.2$ & 2.42 & \\
\cline { 2 - 3 } & $\mathrm{C} 2.3$ & 1.79 & \multicolumn{1}{|c}{} \\
\cline { 2 - 3 } & $\mathrm{C} 2.4$ & 1.96 & \\
\hline
\end{tabular}

Then, according to the weighted average value, the deviations from the average content of mined ores with available minerals in percent, in the developed mine panels are determined (Table 2). After that, taking into account the above discrepancies in the mined minerals content, the planned averaged daily ore output from each panel is substantiated.

Table 1. The planned ore output with averaged content.

\begin{tabular}{|c|c|c|c|}
\hline \multirow{2}{*}{ Panels } & \multicolumn{2}{|c|}{$\begin{array}{c}\text { Deviations from the average } \\
\text { content, \% }\end{array}$} & \multirow{2}{*}{$\begin{array}{c}\text { Averaged daily } \\
\text { output, ton. }\end{array}$} \\
\cline { 2 - 3 } & Copper $(\mathrm{Cu})$ & Zinc $(\mathrm{Zn})$ & \\
\hline 1 & 1.222 & 1.058 & 1025 \\
\hline 2 & 0.904 & 0.835 & 753 \\
\hline 3 & 1.107 & 1.128 & 1006 \\
\hline 4 & 0.852 & 1.031 & 848 \\
\hline
\end{tabular}

The data obtained serve as the basis for scheduling the mineral mining in stope faces of mining enterprise panels during a certain period of field exploitation.

In case of underground mining, the spatial location of each extraction unit at the horizons influences on the operating planning of mining operations. In this regard, to analyse the parameters of averaging the useful components content in extraction units, it is proposed to create a block model of the mined deposits with plans and sections over horizons (Fig. 3).

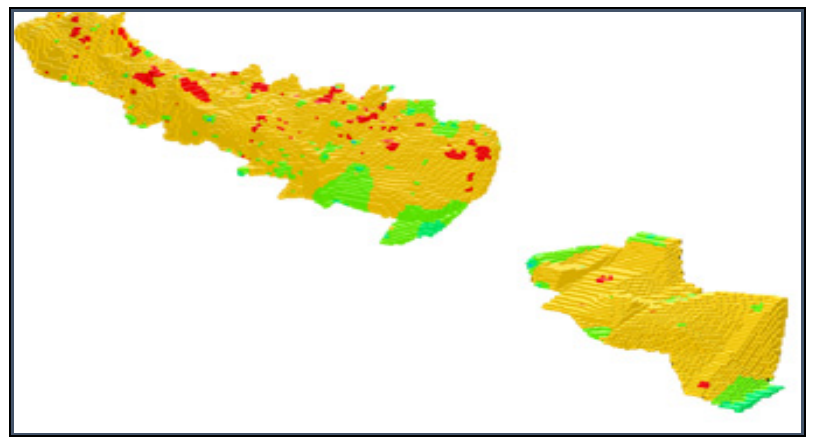

Fig. 3. Block model of the ore body.

Using of such a block model provides an opportunity to work with blocks of various content that differ from the traditional approach. This, in its turn, makes possible to assess with great accuracy the localization of poor and rich ores over horizons. 
As a consequence, such an approach to mining the ores in an underground mine allows calculating of volumes and quality indicators of mineral raw materials in extraction units that are in the process of stope operations, with different contents of useful components.

The change in the volume of mineral raw materials from the planned in separate panels is conditioned by averaging the mineral content by two components of ores mined directly in the course of underground mining operations. Output in the first and third panels exceed the previously planned volumes, and in the second and fourth panels it is reduced in order to ensure the planned ore content. The increase and decrease in output over the panels is explained by the increase in ore output with a low content of useful component, which allows uniform mining of deposits with averaging the mineral raw materials quality. The proposed bottom-hole averaging of the copper-zinc ore content when mining by pillar-andpanel system is shown in Fig. 4.

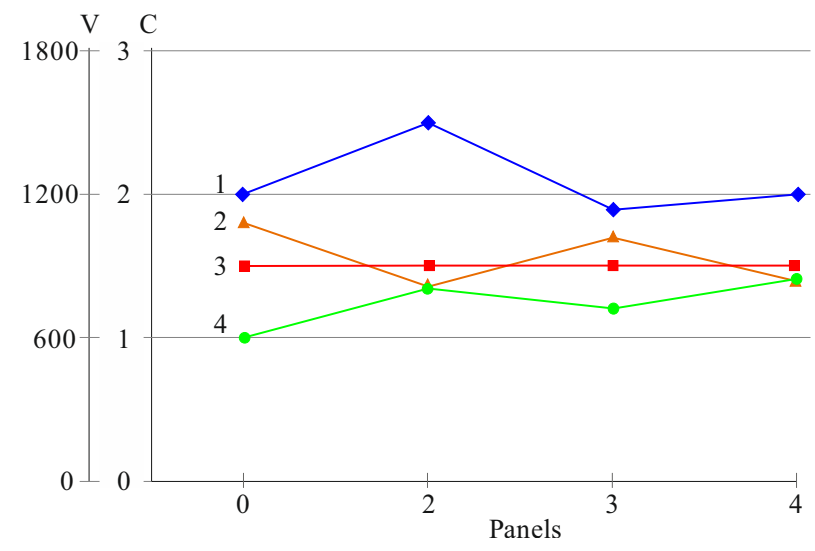

Fig. 4. Bottom-hole averaging of the copper-zinc ore content: 1 -zinc content in the ore; 2 -averaged output; 3 - planned daily output; 4 - copper content in the ore.

Timely production plan implementation at the operating mining enterprise requires substantiation of the planned volumes of extracted mineral raw materials over the panels taking into account its content to ensure the rational development of the subsoil and the rhythmic mine's operation. The presented bottom-hole averaging of the multicomponent ores content, which takes into account the planned volumes and contents of the ore mined over the mined panels, is proposed to be used in underground mining operations. The recommended method of bottom-hole averaging during the underground mining ensures uniform quality of extracted mineral raw materials, supplied to the processing enterprise during a certain period.

\section{Conclusions}

In underground mining operations, stabilization elements for achieving the desired qualitative uniformity of the ore mass include the averaging of its quality, achieved by mixing ore volumes that differ in mineralogical composition. Deviation of the average component content in the ore during the planning period requires taking measures to manage the averaging of its quality. The mined ore content stabilization depends on the order of mining the group of deposits, rational and operating regulation of the output under operation in the existing faces, in accordance with the reserves readiness in extraction units. The change in the mined ore volume in separate panels is explained by averaging the mineral content by two ore components during underground mining operations and 
ensuring the planned ore content mined in them. In general, the sequence of using the bottom-hole averaging depends on the mining-and-geological conditions of the mined deposits and it should be regulated at the stage of scheduling mining operations. Substantiating the optimal option of bottom-hole averaging, which corresponds to the volume and content of ore mined from each panel, is aimed at improving the technical and economic indicators of the deposit mining.

This paper has been prepared within the framework of the result-oriented financing of the Ministry of Education and Science of the Republic of Kazakhstan 2018/BR05235618.

\section{References}

1. Bondarenko, V., Kovalevs'ka, I., \& Ganushevych, K. (2014). Progressive technologies of coal, coalbed methane, and ores mining, 523 p. Book. https://doi.org/10.1201/b17547

2. Khalymendyk, I., \& Baryshnikov, A. (2018). The mechanism of roadway deformation in conditions of laminated rocks. Journal of Sustainable Mining, 17(2), 41-47. https://doi.org/10.1016/j.jsm.2018.03.004

3. Cherniaiev, O.V. (2017). Systematyzatsiia nerudnykh rodovyshch skelnykh korysnykh kopalyn dlia vdoskonalennia tekhnolohii yikh vidpratsiuvannia. Naukovyi Visnyk NHU, (5), 11-17.

4. Mikhlin, Y. V., \& Zhupiev, A. L. (1997). An application of the ince algebraization to the stability of non-linear normal vibration modes. International Journal of Non-Linear Mechanics, 32(2), 393-409. https://doi.org/10.1016/s0020-7462(96)00047-9

5. Sotskov, V., \& Saleev, I. (2013). Investigation of the rock massif stress strain state in conditions of the drainage drift overworking. Annual Scientific-Technical Collection - Mining of Mineral Deposits, 197-201. https://doi.org/10.1201/b16354-35

6. Lomonosov, G.G., \& Turtygina, N.A. (2008). Sistematizatsiya sposobov stabilizatsii sostava rudnoy massy v podzemnom rudnike. Gornyy informatsionno-analiticheskiy byulleten', (12), 120-122.

7. Seredkin, M., Zabolotsky, A., Jeffress, G. (2016) In situ recovery, an alternative to conventional methods of mining: Exploration, resource estimation, environmental issues, project evaluation and economics. Ore Geology Reviews, (79), 500-514. http://dx.doi.org/10.1016/j.oregeorev.2016.06.016

8. Arshamov, Y., Seitmuratova, E., \& Baratov, R. (2015). Perspectives of porphyry copper mineralizations in Zhongar-Balkhash fold system (Kazakhstan). International Multidisciplinary Scientific GeoConference Surveying Geology and Mining Ecology Management, 345-350.

9. Kebede, Ch.D. (2004). Issledovanie $i$ razvitie kombinirovannoy (otkrytopodzemnoy) geotekhnologii s uchetom kachestva rudy i ekologicheskikh posledstviy. PhD Thesis. Moskva: MGGU.

10. Gusmanov, F.F., \& Papunin, A.O. (2016). Problemy i zadachi gornorudnoy promyshlennosti v upravlenii kachestvom produktsii gornogo proizvodstva. Ural'skaya gornaya shkola-regionam, 374-375.

11. Rudko, G.I., Netskyi, O.V., \& Nazarenko, M.V. (2018). The use of geoinformation technologies in economic-geological evaluation of mineral reserves (by the example of K-MINE GIS). 17th International Conference on Geoinformatics - Theoretical and Applied Aspects. https://doi.org/10.3997/2214-4609.201801752

12. Makarov, V.A. (2017) Razrabotka intellektual'noy tekhnologii monitoringa i upravleniya kachestvom rudopotokov pri dobyche i pererabotke mnogokomponentnykh rud. Sovremennye problemy kompleksnoy pererabotki trudnoobogatimykh rud i tekhnogennogo syr'ya, 7-10.

13. Shashenko, A., Gapieiev, S., Solodyankin, A. (2009). Numerical simulation of the elastic-plastic state of rock mass around horizontal workings. Archives of Mining Sciences, 54(2), 341-348.

14. Stupnik, M., Kolosov, V., Kalinichenko, V., Pismennyi, S. (2014). Physical modeling of waste inclusions stability during mining of complex structured deposits. Progressive Technologies of Coal, Coalbed Methane, and Ores Mining, 25-30. https://doi.org/10.1201/b17547. 
15. Malanchuk, Z., Moshynskyi, V., Stets, S., Ignatiuk, I., \& Galiyev, D. (2020). Modelling hydraulic mixture movement along the extraction chamber bottom in case of hydraulic washout of the puffstone. E3S Web of Conference. Preprint.

16. Dychkovskyi, R., Vladyko, O., Maltsev, D., Cabana, E.C. (2018). Some aspects of the compatibility of mineral mining technologies. Rudarsko-Geološko-Naftni Zbornik, 33(4), 73-82. https://doi.org/10.17794/rgn.2018.4.7

17. Turtygina N.A. (2009) Obosnovanie sistemy stabilizatsii kachestva bednykh medno-nikelevykh rud pri podzemnoy dobyche. Doctoral dissertation, M.: MGGU, 26

18. Khugaeva, G. N. (2011). Sostoyanie voprosov usredneniya rudy i planirovaniya gornykh rabot na podzemnykh rudnikakh. Gornyy informatsionno-analiticheskiy byulleten', (10), 211-215.

19. Mustafin, S.A., Duisen, G.M., Zeinullin, A.A., Korobova, E.V. (2019). Evaluation of the choice of borrower rating groups. News of the National Academy of Sciences of the Republic of Kazakhstan, Series of Geology and Technical Sciences, 6(438). https://doi.org/10.32014/2019.2518-170X.166

20. Kozhiev, Kh.Kh. (2005). Klassifikatsiya sposobov upravleniya kachestvom rud pri podzemnoy dobyche. Gornyy informatsionno-analiticheskiy byulleten', (8), 11-13.

21. Lozynskyi, V., Medianyk, V., Saik, P., Rysbekov, K., \& Demydov, M. (2020). Multivariance solutions for designing new levels of coal mines. Rudarsko Geolosko Naftni Zbornik, 35(2), 2332. https://doi.org/10.17794/rgn.2020.2.3

22. Everett, J. (2010). Simulation Modeling of an Iron Ore Operation to Enable Informed Planning. Interdisciplinary Journal of Information, Knowledge, and Management, (5), 101-114. https://doi.org/10.28945/1126

23. Everett, J. (2013). Planning an Iron Ore Mine: From Exploration Data to Informed Mining Decisions. Issues in Informing Science and Information Technology, (10), 145-162. https://doi.org/10.28945/1802

24. Pakhomov, V.P., \& Atamanova, Y.A. (2013). Complex assessment of mineral resources in the conditions of spatial subsurface use. Economy of Region, 69-80. https://doi.org/10.17059/2013-1-6

25. Kozhiev, Kh.Kh., \& Khugaeva, G.N. (2010). Sposoby upravleniya kachestvom rud pri podzemnoy dobyche. Gornyy informatsionno-analiticheskiy byulleten', (4), 24-38

26. Ibrahimov, M., Mohais, A., Schellenberg, S., \& Michalewicz, Z. (2014). Scheduling in iron ore open-pit mining. The International Journal of Advanced Manufacturing Technology, 72(5-8), 1021-1037. https://doi.org/10.1007/s00170-014-5619-8

27. Abdiev A., Mambetova, R., Abdiev, A., \& Abdiev S. (2020). Development of methods for assessing the mine workings stability. E3S Web of Conference. Preprint.

28. Dryzhenko, A., Moldabayev, S., Shustov, A., Adamchuk, A., \& Sarybayev, N. (2017). Open pit mining technology of steeply dipping mineral occurences by steeply inclined sublayers. International Multidisciplinary Scientific GeoConference Surveying Geology and Mining Ecology Management, SGEM, 17(13), 599-606. https://doi.org/10.5593/sgem2017/13/s03.076

29. Richard, A., \& Sulemana, A.H. (2015). Ore grade reconciliation techniques - a review. Journal of Geosciences, 3(5), 116-121.

30. Abdykaparov, C.M., \& Abdiev, A.R. (2002). State and prospects of the development the brown coal deposit in Kara-Keche. Gornyi Zhurnal, (10), 16-19.

31. Vladyko, O., Kononenko, M., \& Khomenko, O. (2012). Imitating modeling stability of mine workings. Geomechanical Processes During Underground Mining, 147-150. https://doi.org/10.1201/b13157-26

32. Babets, D.V., Sdvyzhkova, O.O., Larionov, M.H., Tereshchuk, R.M. (2017). Otsinka stiikosti masyvu hirskykh porid, shcho bazuietsia na ymovirnisnomu pidkhodi ta reitynhovykh klasyfikatsiiakh. Naukovyi visnyk Natsionalnoho Hirnychoho Universytetu, (2), 58-64.

33. Pshennikov, V.A. (2006). Izuchenie protsessa usredneniya rud pri razrabotke uranovykh mestorozhdeniy. Gornyy informatsionno-analiticheskiy byullete', (11), 37-34.

34. Koppelaar, R. H. E. M., \& Koppelaar, H. (2016). The ore grade and depth influence on copper energy inputs. Biophysical Economics and Resource Quality, 1(2), 11. 
35. Golik, V.I., Razorenov, Y.I., \& Lyashenko, V.I. (2018). Conditions of leaching non-ferrous metals from non-commercial reserves. Bulletin of the Tomsk Polytechnic University, Geo Assets Engineering, 329(6), 6-16.

36. Lyashenko, V. (2018). Safety Improving of Mine Preparation Works at the Ore Mines. Bezopasnost' Truda v Promyshlennosti, (5), 53-59. https://doi:10.24000/0409-2961-2018-5-53-59

37. Kieush, L., Yaholnyk, M., Boyko, M., Koveria, A., \& Ihnatenko, V. (2019). Study of biomass utilisation in the iron ore sintering. Acta Metallurgica Slovaca, 25(1), 55. https://doi:10.12776/ams.v1i1.1225

38. Kalybekov, T., Rysbekov, K.B., Soltabaeva, S.T., \& Tursbekov, S.V. (2019). Izuchenie vliyaniyausredneniya rud na obosnovanie podgotovlennosti zapasov na gornykh rabotakh. Vestnik Kyrgyzsko-Rossiyskogo slavyanskogo universiteta, 19(4), 86-92.

39. Kalybekov, T., Rysbekov, K.B., Toktarov, A.A., \& Otarbaev, O.M. (2019). Underground mine planning with regard to preparedness of mineral reserves. Mining Informational and Analytical Bulletin, (5), 34-43.

40. Kalybekov, T., Rysbekov, K.B., \& Soltabayeva, S.T. (2018). The study of the influence of preparedness of the ore reserves on the planning of underground mining operations. Innovative Development of Resource-Saving Technologies of Mineral Mining and Processing, 26-28.

41. Kalybekov, T., Yunussov, R., Rysbekov, K.B., \& Soltabayeva, S.T. (2018). Control of reserves readiness and quality characteristics of ore in open pit mining. World Mining Congress, 220.

42. Rakishev, B. R., \& Galiev, D. A. (2015). Optimization of the ore flow quality characteristics in the quarry in road-rail transport. Metallurgical and Mining Industry, 7(4), 356-362.

43. Raschet normativov zapasov rudy po stepeni podgotovlennosti podzemnykh rudnikov TOO "Korporatsiya Kazakhmys". (2018) P 18-01/09-PZ. TOO "Korporatsiya Kazakhmys". Golovnoy proektnyy institut-Zhezkazgan, 24. 